\title{
Tyrosine Kinase Inhibitors: A Foe for the Thyroid?
}

\author{
Boutzios Georgios, Alexandraki Krystallenia and Kaltsas Gregory* \\ Department of Pathophysiology, National University of Athens, Greece
}

Submission: February 17, 2017; Published: March 07, 2017

*Corresponding author: Gregory Kaltsas, Department of Pathophysiology, Medical school, Endocrine Unit National University of Athens, Greece, Tel: +302107462513; Fax: +302107462664; Email: gkaltsas@endo.gr

\section{Introduction}

Tyrosine kinase inhibitors (TKIs) are agents that inhibit multiple receptor tyrosine kinases that are implicated in tumour growth, neoangiogenesis and metastatic progression of cancer. The simultaneous inhibition of these targets leads to both reduced tumor vascularization and increased cancer cell death, and ultimately tumor shrinkage. Several multi target TKIs are approved and have been associated with thyroid dysfunction [1]. Although anticancer treatment with the TKIs frequently causes thyroid dysfunction, the underlying mechanism implicated along with related clinical features have not been fully elucidated until today.

Anticancer Mechanisms of TKIs Implicated to Thyroid Dysfunction

Angiogenesis, which is also implicated in thyroid function by increasing vascularity in the gland, is a complex process which is tightly controlled by a balance between proantigenic and antiangiogenic factors in healthy adults [2]. Angiogenesis is an essential process for tumour growth and metastasis [2]. Vascular endothelial growth factor (VEGF) is an important proantigenic growth factor which mediates its effects via two related tyrosine kinase receptors: VEGFR-1 and VEGFR-2 $[3,4]$. Thus given the important role of VEGF and platelet-derived growth factor receptor (PDGF) in angiogenesis, targeting of both VEGFR and PDGFR was investigated as part of an antiangiogenic strategy. VEGF and PDGF are important proantigenic growth factors. Upon binding to cell-surface receptors located on endothelial cells and pericytes, the tyrosine kinase within the receptor is activated and an intracellular signalling cascade is initiated which results in cell proliferation, recruitment of endothelial cell precursors and the formation of new capillaries [3,5]. PDGF is also important proantigenic growth factor acting through binding to the tyrosine kinase receptors, PDGFR $\alpha$ and PDGFR $\beta$ [3]. PDGFR- $\beta$ signaling in pericytes is important for the maturation, maintenance and survival of established vessels [6,7]. Pericytes can be significant contributors to the survival of new endothelial cell tubes through direct cell-to-cell contact and paracrine signaling $[8,9]$. After inhibition of VEGF signaling, some normal capillaries regress in a systematic sequence of events initiated by a cessation of blood flow and subsequent apoptosis of endothelial cells, migration of pericytes away from regressing vessels, and formation of empty basement membrane sleeves that can facilitate capillary re-growth [10].

\section{TKIs: Impact on Thyroid Function}

Many studies clearly have demonstrated that TKIs, through blocking molecular pathways, could induce thyroid abnormalities including hypothyroidism and less often hyperthyroidism. A recent meta-analysis has demonstrated that TKIs already employed for the treatment of various cancers sunitinib, cediranib and axitinib have been found to be associated with a significantly increased risk of hypothyroidism. There was no difference on clinical presentation and endocrine parameters between sunitinib and cediranib induced hypothyroidism [11]. However, sunitinib seems to have a major impact on thyroid dysfunction compared to the other TKIs possibly related to its broader spectrum of tyrosine kinases targeting, including not only VEGFR2, but also VEGFR1 and the PDGFR. This specific sunitinib effect implies that all these three mediators play an important role during angiogenesis in the thyroid [12]. Consequently, there are many reports suggesting that sunitinib-induced persistent hypothyroidism may be a consequence of preceding destructive thyroiditis with transient thyrotoxicosis [13-15]. Kappers et al. [16] found a possible mechanism implicated in thyroid dysfunction and showed that sunitinib induces hypothyroidism due to alterations in thyroxine to triiodothyronine [T(4)/T(3)] metabolism as well as thyroid capillary regression [16].

Concerning other TKIs, a previous study has shown that there is an inappropriate elevation of serum thyrotropin levels in patients treated with axitinib, and a similar although less 
prominent tendency, in some patients treated with sunitinib or sorafenib [17]. It has been reported that axitinib may have more rapid impact on thyroid function compared to other TKIs agents [18]. Sorafenib related thyroid dysfunction is much less common compared to sunitinib, ranging between 20 and 36\% [19]. Moreover, when the effects of axitinib were compared to sorafenib in patients with metastatic renal cell cancer, the reported incidence of adverse events including hypothyroidism were more commonly with axitinib [20]. Pazopanib was evaluated in a phase III study in patients with locally advanced or metastatic renal cell carcinoma, and it was found that the incidence of hypothyroidism was less than $10 \%$ [21]. Although treatment with imatinib was not associated with an increased incidence of thyroid dysfunction the number of patients studied was relatively small to make definite conclusions. [22]. A recent report showed that Graves' disease occurred after two different TKIs (sorafenib and imatinib), suggesting that it could be a rare but important class effect [23]. Finally, cabozantinib treatment commonly results in thyroid dysfunction that can vary from subclinical hypothyroidism to florid thyrotoxicosis. Early detection and characterization of cabozantinib-associated thyroid dysfunction and regular follow-up are essential to provide adequate management of this common adverse event [24].

\section{Conclusion}

In conclusion, following the increasing application of TKIs for the treatment of cancer it became apparent that thyroid dysfunction is probably a common effect of treatment with these agents. Thus, evaluation of thyroid function after TKIs initiation is essential. However there are still no clear established guidelines with regard to the treatment of thyroid dysfunction induced by TKIs.

\section{References}

1. Ahmadieh H, Salti I (2013) Tyrosine kinase inhibitors induced thyroid dysfunction: a review of its incidence, pathophysiology, clinical relevance, and treatment. Biomed Res Int 2013: 725410.

2. Hicklin DJ, Ellis LM (2005) Role of the vascular endothelial growth factor pathway in tumor growth and angiogenesis. J Clin Oncol 23(5): 1011-1027.

3. Faivre S, Demetri G, Sargent W, Raymond E (2007) Molecular basis for sunitinib efficacy and future clinical development. Nat Rev Drug Discov 6(9): 734-745.

4. Ferrara N, Gerber HP, Le Couter J (2003) The biology of VEGF and its receptors. Nat Med 9(6): 669-676.

5. Mena AC, Pulido EG, Guillén Ponce C (2010) Understanding the molecular-based mechanism of action of the tyrosine kinase inhibitor: sunitinib. Anticancer Drugs 21 (Suppl 1): S3-S11.

6. Bergers G, Song S, Meyer Morse N, Bergsland E, Hanahan D (2003) Benefits of targeting both pericytes and endothelial cells in the tumor vasculature with kinase inhibitors. J Clin Invest 111(9): 1287-1295.

7. Saharinen P, Alitalo K (2003) Double target for tumor mass destruction. J Clin Invest 111(9): 1277-1280.
8. Benjamin LE, Hemo I, Keshet E (1998) A plasticity window for blood vessel remodelling is defined by pericyte coverage of the preformed endothelial network and is regulated by PDGF-B and VEGF. Development 125(9): 1591-1598.

9. Pietras K, Sjöblom T, Rubin K, Heldin CH, Ostman A (2003) PDGF receptors as cancer drug targets. Cancer Cell 3(5): 439-443.

10. Baffert F, Le T, Sennino B, Thurston G, Kuo CJ, et al. (2006) Cellular changes in normal blood capillaries undergoing regression after inhibition of VEGF signaling. Am J Physiol Heart Circ Physiol 290(2): H547-H559.

11. Abdel Rahman 0, Fouad M (2014) Risk of thyroid dysfunction in patients with solid tumors treated with VEGF receptor tyrosine kinase inhibitors: a critical literature review and meta analysis. Expert Rev Anticancer Ther 14(9): 1063-1073.

12. Makita N, Iiri T (2013) Tyrosine kinase inhibitor-induced thyroid disorders: a review and hypothesis. Thyroid 23(2): 151-159.

13. Sato S, Muraishi K, Tani J, Sasaki Y, Tokubuchi I, et al. (2010) Clinical characteristics of thyroid abnormalities induced by sunitinib treatment in Japanese patients with renal cell carcinoma. Endocr J 57(10): 873880.

14. Sakurai K, Fukazawa H, Arihara Z, Yoshida K (2010) Sunitinib-induced thyrotoxicosis followed by persistent hypothyroidism with shrinkage of thyroid volume. Tohoku J Exp Med 222(1): 39-44.

15. Grossmann M, Premaratne E, Desai J, Davis ID (2008) Thyrotoxicosis during sunitinib treatment for renal cell carcinoma. Clin Endocrinol (Oxf) 69(4): 669-672.

16. Kappers MH, van Esch JH, Smedts FM, de Krijger RR, Eechoute K, et al. (2011) Sunitinib-induced hypothyroidism is due to induction of type 3 deiodinase activity and thyroidal capillary regression. J Clin Endocrinol Metab 96(10): 3087-3094.

17. Ohba K, Takayama T, Matsunaga H, Matsushita A, Sasaki S, et al. (2013) Inappropriate elevation of serum thyrotropin levels in patients treated with axitinib. Thyroid 23(4): 443-448.

18. Daimon M, Kato T, Kaino W, Takase K, Karasawa S, et al. (2012) Thyroid dysfunction in patients treated with tyrosine kinase inhibitors, sunitinib, sorafenib and axitinib, for metastatic renal cell carcinoma. Jpn J Clin Oncol 42(8): 742-747.

19. Tamaskar I, Bukowski R, Elson P, Ioachimescu AG, Wood L, et al. (2008) Thyroid function test abnormalities in patients with metastatic renal cell carcinoma treated with sorafenib. Ann Oncol 19(2): 265-268.

20. Rini BI, Escudier B, Tomczak P, Kaprin A, Szczylik C, et al. (2011) Comparative effectiveness of axitinib versus sorafenib in advanced renal cell carcinoma (AXIS): a randomised phase 3 trial. Lancet 378(9807): 1931-1939.

21. Sternberg CN, Davis ID, Mardiak J, Szczylik C, Lee E, et al. (2010) Pazopanib in locally advanced or metastatic renal cell carcinoma: results of a randomized phase III trial. J Clin Oncol 28(6): 1061-1068.

22. de Groot JW, Zonnenberg BA, Plukker JT, van Der Graaf WT, Links TP (2005) Imatinib induces hypothyroidism in patients receiving levothyroxine. Clin Pharmacol Ther 78(4): 433-438.

23. Eroukhmanoff J, Castinetti F, Penel N, Salas S (2016) Auto-immune thyroid dysfunction induced by tyrosine kinase inhibitors in a patient with recurrent chordoma. BMC Cancer 16: 679.

24. Yavuz S, Apolo AB, Kummar S, del Rivero J, Madan RA, et al. (2014) Cabozantinib-induced thyroid dysfunction: a review of two ongoing trials for metastatic bladder cancer and sarcoma. Thyroid. 24(8): 1223-1231. 
This work is licensed under Creative Commons Attribution 4.0 Licens DOI: 10.19080/JETR.2017.01.555555
Your next submission with Juniper Publishers will reach you the below assets

- Quality Editorial service

- Swift Peer Review

- Reprints availability

- E-prints Service

- Manuscript Podcast for convenient understanding

- Global attainment for your research

- Manuscript accessibility in different formats ( Pdf, E-pub, Full Text, Audio)

- Unceasing customer service

Track the below URL for one-step submission https://juniperpublishers.com/online-submission.php 